\title{
Wymiar handlowy stosunków gospodarczych USA z ChRL w latach 2000-2015
}

\section{Wprowadzenie}

Współpraca handlowa stanowi ważny element stosunków dwustronnych między Stanami Zjednoczonymi Ameryki a Chińską Republiką Ludową. O tym świadczy chociażby fakt rozwijania wzajemnych relacji handlowych praktycznie od początku istnienia państwa amerykańskiego. Celem niniejszego opracowania jest określenie znaczenia wymiany handlowej między Stanami Zjednoczonymi Ameryki a Chińską Republiką Ludową w latach 2000-2014. Realizacja założonego celu nastąpi poprzez ocenę wielkości i dynamiki obrotów handlowych między USA i ChRL. Następnie podjęta zostanie próba analizy struktury przedmiotowej wymiany handlowej między ChRL i USA. Metoda badawcza wykorzystana w opracowaniu to analiza danych wtórnych dotyczących obrotów handlowych między USA i ChRL. Źródła danych statystycznych to International Trade Center oraz United National Conference on Trade Development.

\section{Wielkość i dynamika obrotów handlowych}

Punktem wyjścia wskazania znaczenia wymiany handlowej dla USA i ChRL jest przedstawienie wielkości wzajemnych obrotów po stronie eksportu i importu w badanym przedziale czasowym, przez co będzie możliwa ocena bilansu handlowego. Ponadto warto zwrócić uwagę na dynamikę obrotów między Stanami Zjednoczonymi i Chinami także po stronie eksportu i importu, jak również absolutne udziały amerykańskie w chińskim handlu zagranicznym i odwrotnie. 
Charakteryzując powiązania handlowe USA i ChRL należy zauważyć stały wzrost wzajemnych obrotów, zarówno po stronie eksportu, jak i importu (wykres 1). Analiza tych wartości wskazuje wyraźnie na występowanie trzech charakterystycznych okresów. Pierwszy obejmuje lata 2000-2008, drugi: lata 2009-2014 i trzeci to rok 2015. W pierwszym roku analizy wartość amerykańskiego eksportu na rynek chiński wyniosła ponad 16 mld dolarów przy całkowitej wielkości amerykańskiego eksportu 780 mld dolarów, a wartość chińskiego eksportu na rynek amerykański była równa 107 mld dolarów przy całkowitej wartości chińskiego eksportu na rynki światowe na poziomie 249 mld dolarów. W latach 2000-2008 wielkość obrotów handlowych między USA i ChRL wzrosła prawie 3,5-krotnie, przy czym wartość eksportu amerykańskiego do Chin wzrosła 4,4-krotnie, a wartość importu z ChRL - ponad 3,3-krotnie. W 2009 roku na skutek kryzysu światowego Stany Zjednoczone odnotowały spadek obrotów handlowych z ChRL, zarówno po stronie eksportu (spadek o około 3\%), jak i importu (spadek o ponad 16\%). Sytuacja zdecydowanie się poprawiła już w 2010 roku, czego przejawem był wyraźny wzrost eksportu i importu między tymi państwami, w stosunku do roku poprzedniego odpowiednio o 32,1\% i 17,9\%. Trend wzrostowy został utrzymany również w latach 2011-2014. W 2014 roku, w porównaniu z rokiem 2010, amerykański eksport do Chin był większy o kolejne $34,6 \%$, a import o $27,9 \%$. W 2015 roku w handlu wzajemnym zaobserwowano spadek obrotów po stronie amerykańskiego eksportu na rynek chiński (spadek w stosunku do 2014 roku o 6,06\%) oraz wzrost po stronie amerykańskiego importu z rynku chińskiego (wzrost w stosunku do roku 2014 o 7,7\%).

Przedstawiając wielkość obrotów handlowych pomiędzy Chinami a USA warto zaznaczyć, że w przedziale czasowym 2000-2015 eksport amerykański do Chin wzrósł ponad 7-krotnie, a eksport chiński do USA - ponad 4,5-krotnie. W tym miejscu warto postawić pytanie - co spowodowało tak gwałtowny wzrost? W przypadku wzrostu eksportu z Chin do USA na uwage zasługuje coraz bardziej agresywna polityka Pekinu, która powoduje, że Państwo Środka stało się globalnym inwestorem i eksporterem nowoczesnych rozwiązań technologicznych, co umocniło również jego pozycję polityczną ${ }^{1}$. Wzrostowi eksportu z Chin do USA także sprzyjało to, że przez ponad 20 lat

115 lat temu wywiad USA opublikował prognozy na 2015 roku. W wielu przypadkach sie nie pomylit, „Polityka”, http://www.polityka.pl/tygodnikpolityka/swiat/1623809,1,15-lat-temu-wywiad-usa-opublikowal-prognozy-na-2015-r-w-wielu-przypadkach -sie-nie-pomylil.read (dostęp: 10.03.2016). 
amerykańska polityka handlowa bazowała na nienakładaniu ceł antysubsydyjnych na Chiny i inne kraje o gospodarce nierynkowej².

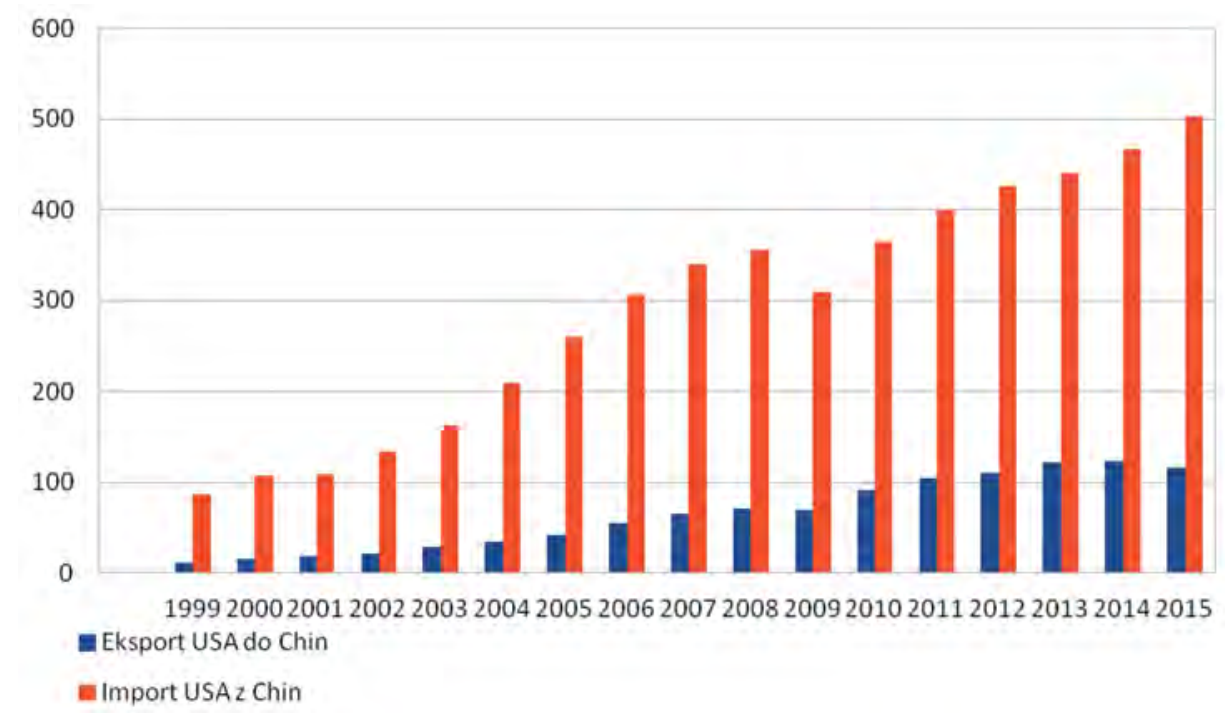

Wykres 1. Wielkość obrotów handlowych między USA a ChRL w latach 2000-2015 (w mld dolarów) Źródło: opracowanie własne na podstawie United Nations Conference on Trade and Development, unctadstat.unctad.org/wds/TableViewer/tableView.aspx (dostęp: 25.02.2015) oraz International Trade Center, http://www.trademap.org/Bilateral_TS.aspx (dostęp: 25.02.2016).

Ponadto, należy uwzględnić i ten fakt, że reformy ekonomiczne wprowadzane od 1979 roku w Chinach przyniosły temu państwu olbrzymi wzrost gospodarczy. W okresie 1979-2005 przeciętny roczny wzrost PKB wyniósł 9,7\%, a w latach 2006-2011 - 11,2\%. Tak gwałtowna ekspansja ekonomiczna Chin ma szereg konsekwencji dla USA. Po pierwsze, Chiny są coraz bardziej atrakcyjnym rynkiem zbytu dla amerykańskich towarów. Po drugie, rosnąca zamożność chińskiego społeczeństwa pozwala na eksport do Chin coraz droższych i bardziej zaawansowanych technologicznie produktów amerykańskich. Po trzecie, Państwo Środka jest także źródłem importu tanich dóbr, co pozwala na utrzymanie niskiej inflacji w USA oraz na zwiększenie popytu na inne towary i usługi ${ }^{3}$. Wracając do kwestii analizy wymiany handlowej amerykańsko-chińskiej warto zwrócić uwagę na bilans handlowy.

2 Nowa polityka USA wobec Chin - cła wyrównawcze na import powlekanego papieru, http://gca.org.pl/pl_PL/usa-congress-eyes-china-trade-action/ (dostęp: 10.03.2016).

3 P. Pacuła, Duopol 2020? Stan relacji amerykańsko-chińskich i perspektywy ich rozwoju, „Bezpieczeństwo narodowe” 2011, nr 20, tom IV, s. 42-43. 
I tak, w całym analizowanym okresie USA odnotowywały ujemne saldo obrotów handlowych z ChRL, podczas gdy dla ich azjatyckiego partnera wskaźnik ten cechował się wartością dodatnią. Co więcej, wraz ze wzrostem amerykańsko-chińskich obrotów handlowych dla USA powiększała się wartość deficytu handlowego z Chinami. Tendencja ta utrzymywała się i w 2008 roku, kiedy to ujemne saldo handlowe USA w handlu z ChRL wyniosło ponad 284 mld dolarów. W 2009 roku, na skutek kryzysu światowego, USA odnotowały nieznaczną redukcję deficytu handlowego w handlu z ChRL do poziomu zbliżonego do roku 2005, czyli około 240 mld dolarów. Jednak oznaczało to, iż kryzys światowy pozytywnie wpłynął na saldo amerykańsko-chińskich obrotów handlowych, ponieważ dynamika spadku importu była wyższa od dynamiki spadku eksportu o 10,5 p.p. W 2010 roku deficyt handlowy ponownie osiągnął wartość zbliżoną do wartości z okresu przedkryzysowego. Jednak należy zaznaczyć, iż w kolejnych latach obserwuje się dalszy jego przyrost, co można uznać za swego rodzaju wzrost zależności USA od importu z ChRL. Mimo że w badanym okresie ujemne saldo amerykańsko-chińskich obrotów handlowych głównie wykazywało tendencję wzrostową, to jednak biorąc pod uwagę deficytowość wyrażoną relacją deficytu handlowego do eksportu amerykańskiego na rynek chiński, można wskazać tendencję spadkową, ponieważ zmniejszyła się ona z poziomu $562 \%$ w roku 2000 do $277 \%$ w roku 2014. W roku 2015 zaobserwowano ponowny wzrost wskaźnika do poziomu 333\%. Chociaż w badanym przedziale czasowym ChRL w handlu z USA cechował dodatni bilans handlowy, to i w jego przypadku wskaźnik ten zmniejszył się z poziomu $84,9 \%$ do $76,9 \%$.

Dlaczego Stany Zjednoczone w handlu z Chinami mają ujemne saldo handlowe? Powód wydaje się być prosty. Amerykańscy przywódcy od lat stosowali politykę otwartych drzwi wobec chińskiego eksportu. Jednocześnie ignorowali blokadę, jaką Pekin zastosował wobec praktycznie wszelkiego eksportu zaawansowanej produkcji amerykańskiej. W wyniku tego USA mają nie tylko ujemne saldo wymiany handlowej z Chinami, lecz stały się także największą ofiarą chińskiego protekcjonizmu

Od czasu wejścia Chin do Światowej Organizacji Handlu (WTO) w 2001 roku szereg palących, czasem także zadawnionych kwestii mobilizuje rządy obu państw. Z punktu widzenia Waszyngtonu pogłębianie się deficytu handlowego jest podsycane zaniżonym kursem yuana oraz

4 Obama $w$ Chinach: zabieranie dziecku cukierka, http://3obieg.pl/obama-w-chinach -zabieranie-dziecku-cukierka (dostęp: 10.03.2016). 
naruszaniem na ogromną skalę amerykańskiej własności przemysłowej i intelektualnej przez chińskie przedsiębiorstwa. Innym, ściśle z nimi powiązanym zagadnieniem, istotnym dla Stanów Zjednoczonych jest wprowadzenie w życie umowy akcesyjnej do WTO, a zwłaszcza zasad odnoszących się do okresu przejściowego. Na przykład w kwietniu 2004 roku, wspólnie z Unią Europejską i Japonią, administracja prezydenta George’a W. Busha wszczęła swoje pierwsze postępowanie przeciw Chinom na forum WTO, by wymusić na nich zniesienie podatku VAT nałożonego na import półprzewodników. W 2007 roku, także wespół z Brukselą, Waszyngton rozpoczął kolejną oficjalną akcję przeciwko nałożonym przez Pekin cłom na import części do samochodów ${ }^{5}$.

Rząd ChRL, przeciwnie, koncentruje swoje działania na zniesieniu narzędzi antydumpingowych, stosowanych przez Stany Zjednoczone wobec chińskich przedsiębiorstw. Owe liczne środki pozwalają bowiem na zapewnienie lepszej ochrony amerykańskim firmom, które uważają, że chińska konkurencja jest nieuczciwa. Przystępując do WTO, Chiny zgodziły się nie korzystać do 2015 roku ze statusu gospodarki rynkowej, co ułatwia działania antydumpingowe, dlatego też Pekin walczy, by uzyskać upragnioną pozycję wcześniej niż przewiduje umowa. Jednak, ani Bruksela, ani Waszyngton, ani Tokio nie ustępują ze względu na liczne i nieprzejrzyste bariery chroniące w dalszym ciągu rynek chiński ${ }^{6}$.

W przypadku zmniejszenia deficytu handlowego, USA mają jednak niewielkie pole manewru. Wprowadzenie ceł, kontyngentów lub innych form ograniczania importu byłoby naruszeniem zasad Światowej Organizacji Handlu i niekorzystnie wpłynęłoby na stosunki z Pekinem. Część ekspertów bagatelizuje problem deficytu przekonując, że import towarów materiałochłonnych i pracochłonnych nie jest szkodliwy dla gospodarki amerykańskiej, której rozwój opiera się na innowacyjności, nowoczesnych technologiach oraz usługach. W stwierdzeniu tym jest tylko część prawdy. Po pierwsze, chiński przemysł produkuje towary o coraz większym stopniu zaawansowania. Po drugie, można zauważyć tendencję do kupowania znanych marek lub współpracy z uznanymi producentami z branży nowoczesnych technologii. Tendencja ta pogłębia negatywne dla Stanów Zjednoczonych implikacje rosnącego deficytu handlowego ${ }^{7}$.

5 J.-P. Cabestan, Polityka zagraniczna Chin, Warszawa 2013, s. 229-230.

6 Ibidem, s. 230.

7 P. Pacuła, op. cit., s. 45. 
Karolina Kotulewicz-Wisińska

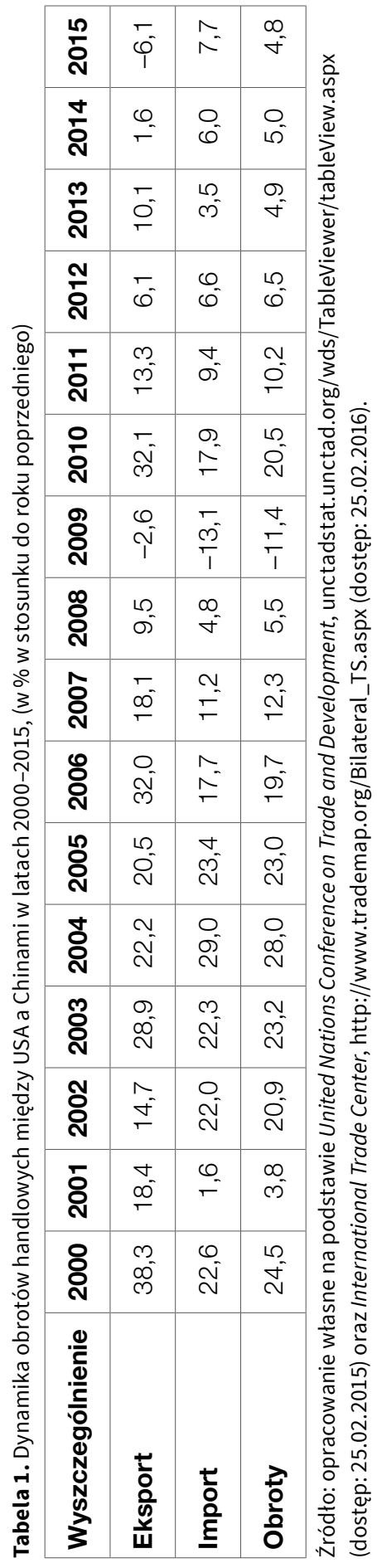


I tak, średnioroczna dynamika wzrostu amerykańskiego eksportu na rynek ChRL wynosiła $23,81 \%$ i była ona wyższa od średniorocznej dynamiki chińskiego eksportu na rynek USA ogółem o 4,31 p.p. (tabela 1). Stopa wzrostu amerykańskiego eksportu na rynek chiński w 2014 roku, w stosunku do początkowego roku analizy, wyniosła $761 \%$, podczas gdy stopa wzrostu chińskiego eksportu na rynek amerykański była równa $433,7 \%$. W początkowych latach obserwuje się spadek dynamiki amerykańskiego eksportu na rynek chiński oraz chińskiego eksportu na rynek amerykański. Natomiast w 2004 roku miał miejsce bardzo dynamiczny wzrost przede wszystkim eksportu z Chin na rynek USA, przekraczający wartość $28 \%$ w stosunku do roku poprzedniego. Choć relacja dynamiki amerykańskiego eksportu na rynek chiński do dynamiki chińskiego eksportu na rynek amerykański wskazuje na występowanie podobnych trendów, to jednak w tym drugim przypadku cechowała się ona prawie dwukrotnie mniejszym wzrostem.

Biorąc pod uwagę wyżej przedstawione dane dotyczące wielkości i dynamiki amerykańsko-chińskich obrotów handlowych, należy zauważyć, że wartości te, zarówno po stronie eksportu, jak i importu, cechowały się systematycznym wzrostem. Wyjątek stanowił rok 2009.

W latach 2000-2014 udział amerykańskiego eksportu do ChRL w eksporcie USA ogółem był prawie sześciokrotnie mniejszy od udziału chińskiego eksportu do USA w eksporcie ChRL ogółem (tabela 2). Natomiast udział amerykańskiego importu z ChRL w imporcie USA ogólem był ponad dwukrotnie większy od udziału chińskiego importu z USA w imporcie ChRL ogółem. W tym samym czasie średni udział eksportu USA do Chin w globalnym eksporcie USA wynosił 3,36\%, podczas gdy udział chińskiego eksportu do USA w globalnym eksporcie Chin prawie 30\%.

Tabela 2. Udział USA $w$ handlu zagranicznym ChRL oraz udział ChRL w handlu zagranicznym USA w latach 2000-2014 (w \%)

\begin{tabular}{|c|c|c|c|c|c|c|}
\hline \multirow{2}{*}{ Rok } & \multicolumn{3}{|c|}{$\begin{array}{c}\text { Udział USA w handlu zagranicznym } \\
\text { Chin }\end{array}$} & \multicolumn{3}{|c|}{ Udział Chin w handlu zagranicznym } \\
USA \\
\cline { 2 - 7 } & $\begin{array}{c}\text { Import } \\
\text { Chin }\end{array}$ & $\begin{array}{c}\text { Eksport } \\
\text { Chin }\end{array}$ & $\begin{array}{c}\text { Obroty USA } \\
\text { z Chinami }\end{array}$ & $\begin{array}{c}\text { Import } \\
\text { USA }\end{array}$ & $\begin{array}{c}\text { Eksport } \\
\text { USA }\end{array}$ & $\begin{array}{c}\text { Obroty Chin } \\
\text { z USA }\end{array}$ \\
\hline 1 & 2 & 3 & 4 & 5 & 6 & 7 \\
\hline 2000 & 7,22 & 43,18 & 26,12 & 8,55 & 2,08 & 6,08 \\
\hline 2001 & 7,90 & 41,11 & 25,24 & 9,27 & 2,63 & 6,73 \\
\hline 2002 & 7,47 & 41,00 & 25,06 & 11,10 & 3,18 & 8,21 \\
\hline 2003 & 6,88 & 37,25 & 22,52 & 12,51 & 3,93 & 9,45 \\
\hline
\end{tabular}


Tabela 2. (cd.)

\begin{tabular}{|c|c|c|c|c|c|c|}
\hline 1 & 2 & 3 & 4 & 5 & 6 & 7 \\
\hline 2004 & 6,19 & 35,48 & 21,24 & 13,80 & 4,25 & 10,47 \\
\hline 2005 & 6,34 & 34,10 & 21,22 & 15,00 & 4,63 & 11,44 \\
\hline 2006 & 6,98 & 31,56 & 20,51 & 15,93 & 5,33 & 12,21 \\
\hline 2007 & 6,82 & 27,88 & 18,63 & 16,86 & 5,61 & 12,75 \\
\hline 2008 & 6,31 & 24,90 & 16,69 & 16,46 & 5,50 & 12,35 \\
\hline 2009 & 6,92 & 25,76 & 17,18 & 19,32 & 6,58 & 14,26 \\
\hline 2010 & 6,71 & 23,13 & 15,50 & 19,08 & 7,19 & 14,32 \\
\hline 2011 & 5,97 & 21,03 & 13,82 & 18,11 & 7,03 & 13,65 \\
\hline 2012 & 6,08 & 20,77 & 13,86 & 18,71 & 7,15 & 14,04 \\
\hline 2013 & 6,24 & 19,93 & 13,51 & 19,43 & 7,72 & 14,62 \\
\hline 2014 & 6,32 & 19,92 & 13,73 & 19,89 & 7,64 & 14,89 \\
\hline
\end{tabular}

Źródło: opracowanie własne na podstawie United Nations Conference on Trade and Development, unctadstat.unctad.org/wds/TableViewer/tableView.aspx (dostęp: 25.02.2015) oraz International Trade Center, http://www.trademap.org/Bilateral_TS.aspx (dostęp: 25.02.2016).

Zawarte powyżej dane jednak pokazują, że większą zależność od handlu z USA cechuje ChRL. Na przestrzeni lat 2000-2014 udział amerykańsko-chińskich obrotów handlowych w PKB USA średnio wynosił 2,47\%, a w PKB ChRL - 9,46\%. Mimo to w badanym przedziale nieznacznie wzrósł stopień względnej zależności amerykańskiej i chińskiej gospodarki mierzony stosunkiem wzajemnych obrotów do sumy PKB obu państw. Jeśli w 2000 roku stosunek wzajemnego obrotu handlowego do sumy $\mathrm{PKB}$ obu partnerów równał się $1,06 \%$, to w 2014 roku wzrósł do poziomu 1,93\%.

Wszystko to było równoznaczne $\mathrm{z}$ występowaniem znacznej asymetrii w wymianie handlowej między USA i ChRL, jeśli rozpatrywać jej znaczenie w kształtowaniu się wielkości PKB tych krajów, a ściślej w procesach tworzenia się i podziału PKB w USA i w ChRL (tabela 3).

Tabela 3. Udział amerykańsko-chińskiej wymiany handlowej w PKB USA i PKB ChRL w latach 2000-2014 (w \%)

\begin{tabular}{|c|c|c|c|}
\hline Rok & Udział w PKB USA & Udział w PKB Chin & $\begin{array}{c}\text { Udział w PKB } \\
\text { dwóch państw }\end{array}$ \\
\hline 2000 & 1,20 & 10,28 & 1,06 \\
\hline 2001 & 1,21 & 9,65 & 0,97 \\
\hline 2002 & 1,42 & 10,64 & 1,13 \\
\hline
\end{tabular}




\begin{tabular}{|c|c|c|c|}
\hline 2003 & 1,67 & 11,62 & 1,31 \\
\hline 2004 & 2,00 & 12,63 & 1,54 \\
\hline 2005 & 2,30 & 13,30 & 1,74 \\
\hline 2006 & 2,61 & 13,22 & 1,92 \\
\hline 2007 & 2,80 & 11,51 & 1,99 \\
\hline 2008 & 2,91 & 9,38 & 1,96 \\
\hline 2009 & 2,63 & 7,49 & 1,01 \\
\hline 2010 & 3,05 & 7,56 & 1,77 \\
\hline 2011 & 3,24 & 6,72 & 1,97 \\
\hline 2012 & 3,32 & 6,34 & 1,96 \\
\hline 2013 & 3,35 & 5,92 & 1,94 \\
\hline 2014 & 3,39 & 5,70 & 1,93 \\
\hline
\end{tabular}

Źródło: opracowanie własne na podstawie: United Nations Conference on Trade and Development, unctadstat.unctad.org/wds/TableViewer/tableView.aspx (dostęp: 25.02.2015) oraz The World Bank, http://databank.worldbank.org/data/reports.aspx?source=world-development-indicators (dostęp: 25.02.2016).

$\mathrm{Z}$ kolei dane te wskazują na istnienie różnic $\mathrm{w}$ rozwoju gospodarczym obu państw, które wynikają z wielkości PKB wyprodukowanego przez USA i ChRL oraz ze stopnia uzależnienia ich gospodarek od handlu zagranicznego.

\section{Struktura towarowa i rodzajowa}

Analizując w latach 2000-2014 strukturę towarową eksportu USA do Chin (wykres 2), należy zauważyć, że struktura ta była stabilna. Zazwyczaj około $35 \%$ tego eksportu przypadało na maszyny, urządzenia i sprzęt transportowy. Inną, znaczącą pozycją były surowce jadalne i przetwory z nich, w tym zwłaszcza: nasiona i owoce oleiste, złom i rudy metalu, celuloza i makulatura, surowce pochodzenia roślinnego i zwierzęcego oraz drewno. Trzecią znaczącą grupę w amerykańskim eksporcie do Chin stanowiły chemikalia, w tym zwłaszcza: tworzywa sztuczne, chemikalia organiczne i wyroby farmaceutyczne. Natomiast niewielką rolę w eksporcie USA do Chin odgrywały towary przemysłowe, żywność i zwierzęta żywe.

Na uwagę zasługuje także i to, że w badanym przedziale czasowym wszystkie wyżej wymienione grupy towarowe cechował wzrost. Największy wzrost eksportu z USA do Chin odnotowały: napoje i tytoń (ponad 68-krotny); paliwa mineralne (ponad 29-krotny); żywność i zwierzęta żywe (ponad 15-krotny); surowce jadalne (12-krotny); chemikalia (ponad 8-krotny); towary przemysłowe 
według surowca (5-krotny); maszyny, urządzenia i sprzęt transportowy (ponad 4,5-krotny) oraz grupa inne wyroby przemysłowe (7-krotny).

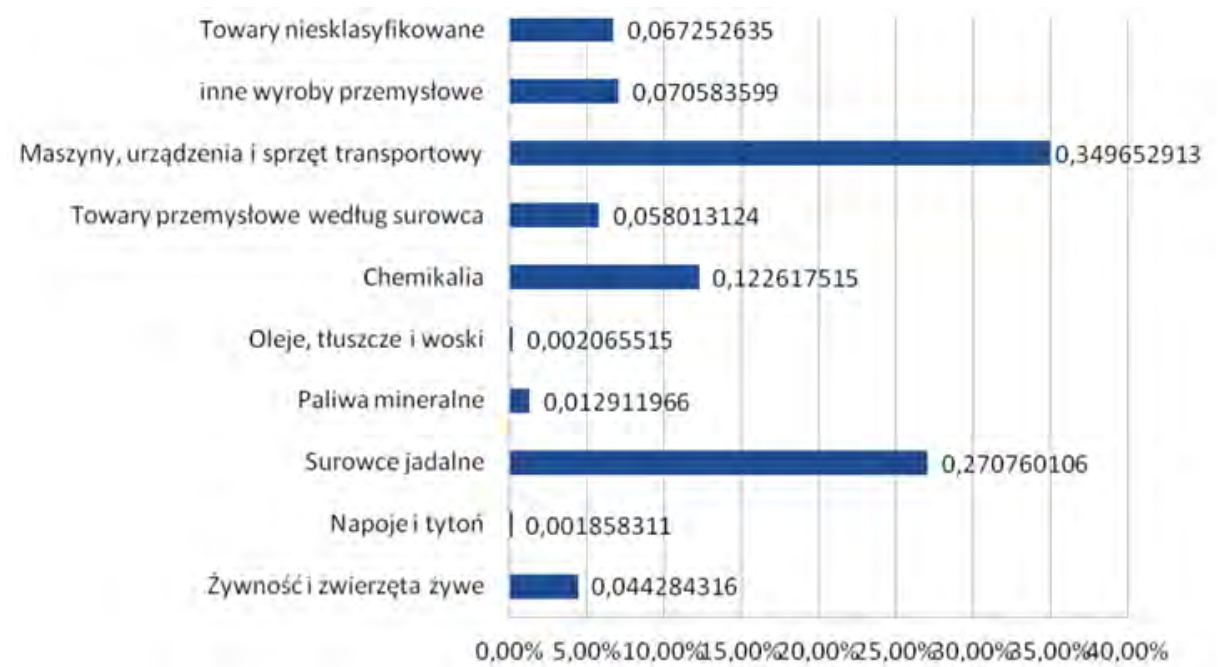

Wykres 2. Struktura towarowa eksportu USA do Chin według jednocyfrowej klasyfikacji SITC w latach 2000-2014 (w \%)

Źródło: opracowanie własne na podstawie United Nations Conference on Trade and Development, unctadstat.unctad.org/wds/TableViewer/tableView.aspx (dostęp: 25.02.2015).

W przypadku struktury towarowej chińskiego eksportu do USA (wykres 3) ponad 45\% przypadało na maszyny, urządzenia i sprzęt transportowy, w tym sprzęt telekomunikacyjny i urządzenia do nagrywania dźwięku; maszyny biurowe i sprzęt do automatycznego przetwarzania danych; maszyny elektryczne, aparaty i urządzenia; inne maszyny przemysłowe i części do nich oraz pojazdy drogowe. Drugą znaczącą grupę towarów stanowią inne wyroby przemysłowe (prawie 36\%). Wśród nich duże znaczenie zajmują takie wyroby, jak: artykuły odzieżowe i dodatki do ubiorów; meble i ich części; obuwie oraz różne wyroby przemysłowe. Trzecią ważną grupą towarową $\mathrm{w}$ eksporcie $\mathrm{z}$ Chin do USA stanowiły towary przemysłowe sklasyfikowane według surowca. W ramach tej grupy duże znaczenie miały: przędza włókiennicza i produkty pochodne; niemetalowe produkty mineralne; wyroby gumowe oraz żelazo i stal. Pozostałe grupy towarowe mają małe znaczenie.

Analizując pod względem struktury towarowej wielkość eksportu z Chin do USA należy zauważyć, że również wymienione grupy towarowe w badanym okresie cechował trend wzrostowy, aczkolwiek nie był on tak znaczący, jak w przypadku amerykańskiego eksportu na rynek chiński. Średnio wzrost ten wyniósł tylko 4,4 razy, wtedy gdy w przypadku amerykańskiego eksportu na rynek chiński - 17,6 razy. 


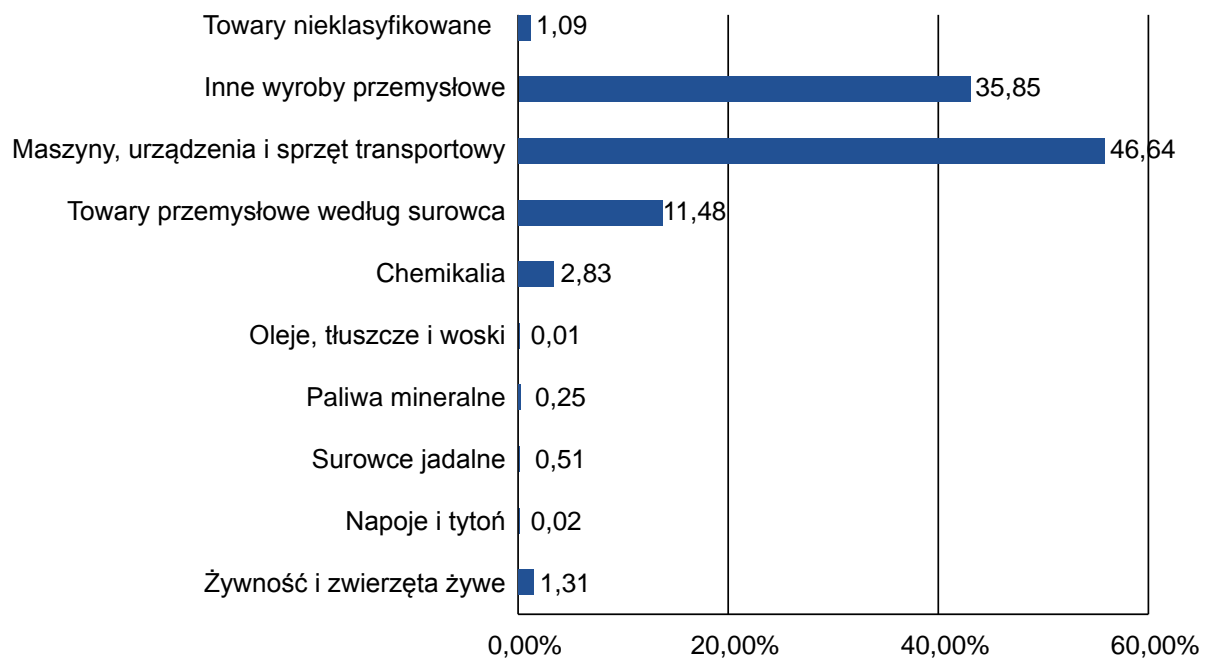

Wykres 3. Struktura towarowa importu USA z Chin według jednocyfrowej klasyfikacji SITC w latach 2000-2014 (w \%)

Źródło: opracowanie własne na podstawie: United Nations Conference on Trade and Development, unctadstat.unctad.org/wds/TableViewer/tableView.aspx (dostęp: 25.02.2015).

\section{Import do USA z Chin}

nieklasyfikowane

tech. intensywne trudne do imitowania

tech. intensywne łatwe do imitowania

kapitałochłonne

pracochłonne

surowcochłonne

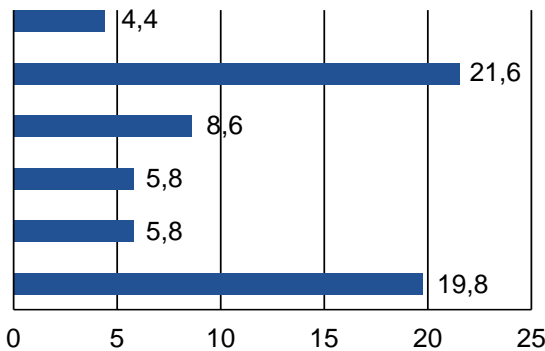

mld USD

Eksport z USA do Chin

nieklasyfikowane

tech. intensywne trudne do imitowania

tech. intensywne łatwe do imitowania

kapitałochłonne

pracochłonne

surowcochłonne

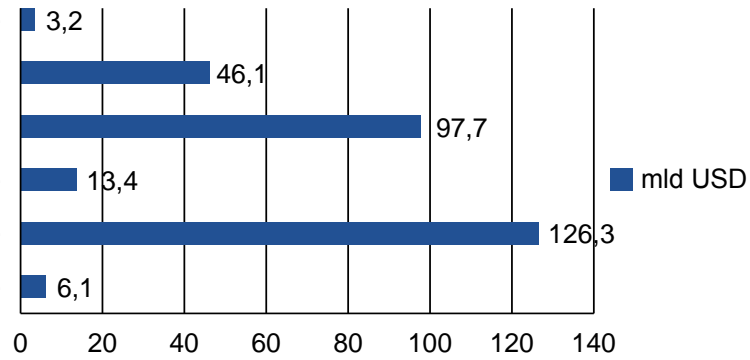

Wykres 4. Struktura rodzajowa wymiany handlowej między USA i ChRL w latach 2000-2014 według dwucyfrowej klasyfikacji SITC (w mld USD)

Źródło: opracowanie własne na podstawie United Nations Conference on Trade and Development, unctadstat.unctad.org/wds/TableViewer/tableView.aspx (dostęp: 25.02.2015). 
Struktura rodzajowa wymiany handlowej między USA i ChRL cechowała się tym, że w badanym przedziale czasowym po stronie amerykańskiego eksportu na rynek chiński dominowały towary technologiczne intensywne trudne do imitowania (21,6 mld dolarów); surowcochłonne (19,8 mld dolarów) oraz technologiczne intensywne trudne do imitowania (8,6 mld dolarów). Natomiast w przypadku chińskiego eksportu na rynek amerykański do grupy tej należały wyroby pracochłonne (126,3 mld dolarów); technologiczne intensywne łatwe do imitowania ( 97,7 mld dolarów), technologiczne intensywne trudne do imitowania (46,1 mld dolarów) oraz wyroby kapitałochłonne (13,4 mld dolarów).

\section{Poziom i struktura ujawnionych przewag komparatywnych}

Analizę zmian struktury amerykańsko-chińskiej wymiany handlowej uzupełnia badanie ujawnionych przewag komparatywnych. Dokonuje się go za pomocą wskaźnika B. Balassy (Revealed Comparative Advantage - RCA), który mierzy relatywną specjalizację eksportową, jak również mierzy korzyści konkurencyjne. Wartość wskaźnika $\mathrm{RCA}_{\mathrm{i}}$ większa od zera świadczy o występowaniu ujawnionej przewagi względnej i wskazuje na intensywność tej przewagi. $\mathrm{W}$ przypadku wskaźników $\mathrm{RCA}_{\mathrm{i}}$ mniejszych od zera mamy do czynienia $\mathrm{z}$ brakiem tego typu przewagi. Użycie postaci logarytmicznej formuły pozwala na zachowanie symetryczności dodatnich i ujemnych wskaźników $\mathrm{RCA}_{\mathrm{i}} \mathrm{w}$ przedziale wahającym się wokół zera8 ${ }^{8}$.

Przewagę komparatywną obliczono według następującego wzoru:

$$
\left.\mathrm{RCA}_{\mathrm{i}}=\ln \frac{\left(\frac{x_{i}}{\sum X}\right.}{\frac{y_{i}}{\sum Y}}\right)
$$

gdzie:

$x_{i}$ - eksport grupy towarowej „i” z USA do ChRL

$y_{i}$ - import grupy towarowej ,i” do USA z ChRL

$\Sigma X$ - ogólna wartość eksportu USA do ChRL w danym roku

$\Sigma Y$ - ogólna wartość importu USA z ChRL w danym roku

$i-$ dział sekcji towarowej

8 J. Misala, Międzynarodowa konkurencyjność gospodarki narodowej, Warszawa 2011, s. 165. 
Wymiar handlowy stosunków gospodarczych USA z ChRL w latach 2000-2015

\begin{tabular}{|c|c|c|c|c|c|c|c|}
\hline & $\stackrel{+}{\text { ¿ }}$ & $\begin{array}{l}\Omega \\
\sim \\
\sim\end{array}$ & $\begin{array}{l}\hat{\theta} \\
\overline{1}\end{array}$ & $\begin{array}{l}\mathscr{Q} \\
\mathscr{O} \\
0\end{array}$ & 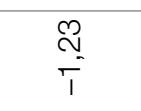 & $\begin{array}{l}M_{0} \\
M_{0}\end{array}$ & \\
\hline & $\frac{m}{\grave{N}}$ & $\begin{array}{l}\infty \\
\infty \\
i \\
\sim\end{array}$ & $\frac{0}{T}$ & $\begin{array}{l}\infty \\
0 \\
0 \\
0\end{array}$ & $\stackrel{\stackrel{Q}{N}}{T}$ & $\begin{array}{l}\stackrel{0}{L} \\
M \\
0\end{array}$ & \\
\hline & ָั & $\begin{array}{l}\stackrel{8}{\Omega} \\
\sim \\
\sim\end{array}$ & $\begin{array}{l}\bar{\tau} \\
\bar{\tau}\end{array}$ & $\begin{array}{l}\frac{N}{0^{\prime}} \\
\text { - }\end{array}$ & $\begin{array}{l}\hat{F} \\
\bar{T}\end{array}$ & $\begin{array}{l}\stackrel{\infty}{N} \\
\underset{0}{0}\end{array}$ & \\
\hline & $\overline{\text { Tे }}$ & $\begin{array}{l}\infty \\
\infty \\
\sim \\
\sim\end{array}$ & $\frac{\text { g }}{T_{1}}$ & $\begin{array}{l}\tilde{N} \\
\infty \\
0 \\
0\end{array}$ & $\begin{array}{l}\hat{O} \\
T_{1}^{-}\end{array}$ & $\begin{array}{l}\text { lo } \\
\text { co }\end{array}$ & \\
\hline & 웅 & $\begin{array}{l}\widetilde{N} \\
\sim \\
\sim\end{array}$ & 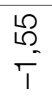 & $\begin{array}{l}\stackrel{L}{2} \\
0^{\circ}\end{array}$ & $\begin{array}{l}\mathcal{O} \\
\tilde{O}_{-}^{-}\end{array}$ & $\begin{array}{l}\text { Oे } \\
0 \\
0\end{array}$ & \\
\hline & ষ্ণ & $\begin{array}{l}\infty \\
\infty \\
\sim\end{array}$ & $\begin{array}{l}\stackrel{R}{R} \\
T_{1}^{-}\end{array}$ & $\begin{array}{l}\text { J } \\
\text { I }\end{array}$ & $\begin{array}{l}\bar{\sigma} \\
\overline{1}\end{array}$ & $\begin{array}{l}\stackrel{+}{\hat{O}} \\
0^{-}\end{array}$ & \\
\hline & ષ્స & 胥 & $\begin{array}{l}0 \\
\mathscr{L} \\
T \\
1\end{array}$ & $\bar{\tau}_{0}$ & $\begin{array}{l}\hat{\alpha} \\
\infty \\
0 \\
\end{array}$ & $\underset{-}{8}$ & \\
\hline & ণ্ণ & $\begin{array}{l}\stackrel{\circ}{\infty} \\
\sim \\
\sim\end{array}$ & $\mathbb{Q}_{1}^{\infty}$ & $\begin{array}{l}\stackrel{\mathscr{N}}{N} \\
0 \\
0\end{array}$ & $\begin{array}{l}0 \\
\infty \\
9\end{array}$ & $F_{F}$ & \\
\hline & ஜั & 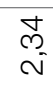 & $\begin{array}{l}\stackrel{\text { m }}{\Gamma} \\
\frac{1}{1}\end{array}$ & $\begin{array}{l}\stackrel{\Delta}{\Delta} \\
\text { Oे }\end{array}$ & $\begin{array}{l}\hat{\alpha} \\
\infty \\
\varphi^{-}\end{array}$ & 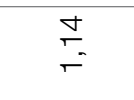 & \\
\hline & ర్సి & $\begin{array}{c}\infty \\
\text { N } \\
\sim\end{array}$ & $\frac{\mathscr{Y}}{\underset{T}{T}}$ & $\begin{array}{l}\tau \\
\text { fo }\end{array}$ & 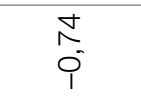 & $\underset{\leftarrow}{\check{F}}$ & \\
\hline & ষ্ণ & 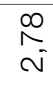 & 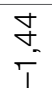 & $\begin{array}{l}\text { Q } \\
0 \\
0\end{array}$ & $\begin{array}{l}\widetilde{0} \\
0 \\
0\end{array}$ & $F_{-}$ & \\
\hline & ర్సి & $\begin{array}{l}\text { Dे } \\
\text { N }\end{array}$ & $\begin{array}{l}8 \\
T_{1}^{-}\end{array}$ & $\overline{0}$ & $\begin{array}{l}n \\
0 \\
0 \\
0\end{array}$ & $\underset{-}{8}$ & \\
\hline & ণ్సి & $\begin{array}{l}\infty \\
\stackrel{\sim}{\sim} \\
\sim\end{array}$ & $\begin{array}{l}\infty \\
\infty \\
T_{1}^{\prime}\end{array}$ & $\frac{10}{\circ}$ & $\begin{array}{l}\text { N } \\
\text { ले } \\
\text { i }\end{array}$ & $\stackrel{\mathbb{N}}{\sim}$ & \\
\hline & ర్ల & $\frac{L}{c}$ & $\begin{array}{l}\text { OS } \\
\sigma_{1}\end{array}$ & $\begin{array}{l}0 \\
\frac{0}{0}\end{array}$ & $\begin{array}{l}0 \\
0 \\
0 \\
0\end{array}$ & $\stackrel{\circ}{\stackrel{\circ}{\digamma}}$ & \\
\hline & ষ্ণ & $\stackrel{\stackrel{g}{\circ}}{\circ}$ & $\frac{\Gamma}{T}$ & $\begin{array}{l}\text { Na } \\
\text { on }\end{array}$ & $\begin{array}{l}\text { L } \\
0 \\
0\end{array}$ & $\underset{\sigma}{\sigma}$ & \\
\hline & 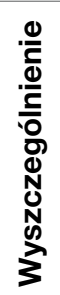 & 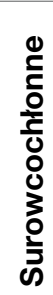 & 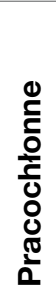 & 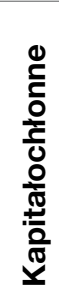 & 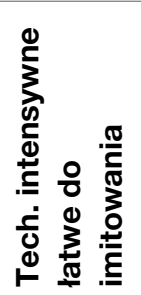 & 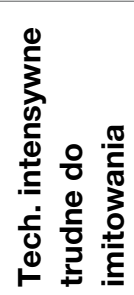 & \\
\hline
\end{tabular}


Wskaźniki ujawnionych przewag względnych $\mathrm{RCA}_{i}$ dla handlu amerykańskiego i chińskiego wskazują, że w badanym okresie USA osiągały przewagę komparatywną w przypadku następujących sekcji: towarów surowcochłonnych, technologicznie intensywnych trudnych do imitowania oraz $\mathrm{w}$ niewielkim stopniu $\mathrm{w}$ przypadku towarów kapitałochłonnych. Z kolei ChRL w handlu z partnerem amerykańskim osiągały przewagę komparatywną w przypadku towarów pracochłonnych oraz w przypadku towarów technologicznych intensywnych łatwych do imitowania. Z powyżej uzyskanych danych wynika, że handel amerykańsko-chiński jest wymianą typu międzygałęziowego.

\section{Intensywność i struktura handlu wewnątrzgałęziowego}

Handel wewnątrzgałęziowy to zjawisko polegające na jednoczesnym imporcie i eksporcie produktów zaliczonych do tej samej gałęzi. Wskaźniki intensywności handlu wewnątrzgałęziowego IIT $_{i}$ w handlu USA z ChRL w latach 2000-2014 obliczono według metody autorstwa dwóch badaczy H. G. Grubela i P. J. Lloyda. Sformułowany przez nich wskaźnik przyjmuje postać:

$$
\operatorname{IIT}_{i}=\frac{x_{i}+y_{i}-\left|x_{i}-y_{i}\right|}{x_{i}+y_{i}}
$$

gdzie:

$x_{i}$ - eksport grupy towarowej „,i” z USA do ChRL

$y_{i}$ - import grupy towarowej ,i” do USA z ChRL

Wskaźnik IIT $_{i}$ mieści się $\mathrm{w}$ granicach $0-1$, przy czym IIT $_{i}=0$ oznacza brak obrotów wewnątrzgałęziowych, zaś IIT $_{i}=1$ oznacza, że obroty mają wyłącznie charakter wewnątrzgałęziowy. Zatem im bliższa 1 jest wartość IIT $_{i}$ (względnie lub), tym większy jest udział handlu wewnątrzgałęziowego w obrotach zagranicznych danej gałęzi bądź danego kraju.

W świetle dotychczasowego dorobku teoretycznego i dotychczasowych doświadczeń rozwoju współczesnej gospodarki światowej intensywność wymiany wewnątrzgałęziowej powinna być coraz wyższa oraz wykazywać stopniową przewagę nad intensywnością typu międzygałęziowego. W handlu amerykańsko-chińskim mamy do czynienie z tendencją odwrotną. Otóż omówionemu wcześniej wzrostowi stopnia i znaczenia wymiany (komplementarności) międzygałęziowej między USA i ChRL towarzyszy spadek intensywności i znaczenia wymiany (komplementarności) typu międzygałęziowego. 
Wymiar handlowy stosunków gospodarczych USA z ChRL w latach 2000-2015

\begin{tabular}{|c|c|c|c|c|c|c|c|}
\hline & సै. & $\begin{array}{l}\hat{M} \\
\hat{O}^{-}\end{array}$ & $\begin{array}{l}\circ \\
\frac{0}{0}\end{array}$ & $\begin{array}{l}0 \\
\infty \\
0 \\
0\end{array}$ & $\frac{⿱}{\check{0}}$ & $\begin{array}{l}\text { L } \\
0 \\
0\end{array}$ & $\sum_{j}^{3}$ \\
\hline & \) & $\begin{array}{l}m \\
m \\
0 \\
0\end{array}$ & $\bar{\sigma}_{0}$ & $\begin{array}{l}\bar{\infty} \\
0^{-}\end{array}$ & $\begin{array}{l}0 \\
0 \\
0\end{array}$ & $\begin{array}{l}\hat{0} \\
\hat{0} \\
0\end{array}$ & $\overline{\mathrm{g}}$ \\
\hline & స్ & $\begin{array}{l}\stackrel{5}{m} \\
\mathrm{O}^{\prime}\end{array}$ & $\begin{array}{l}\stackrel{N}{\check{0}} \\
0^{-}\end{array}$ & $\begin{array}{l}\bar{N} \\
0^{\circ}\end{array}$ & $\frac{10}{5}$ & $\begin{array}{l}0 \\
0 \\
0 \\
0\end{array}$ & $\frac{\pi}{\sigma}$ \\
\hline & స్స & $\begin{array}{l}\stackrel{L}{\infty} \\
m \\
0\end{array}$ & $\bar{E}_{0}$ & $\begin{array}{l}\stackrel{2}{2} \\
0^{\circ}\end{array}$ & $\frac{1}{\sigma}$ & $\begin{array}{l}\infty \\
\stackrel{\infty}{0} \\
0 \\
0\end{array}$ & $\vec{b}_{0,0}$ \\
\hline & 울 & $\begin{array}{l}\infty \\
m \\
0 \\
0\end{array}$ & $\frac{0}{0_{0}}$ & $\begin{array}{l}0 \\
\stackrel{0}{0}\end{array}$ & $\stackrel{n}{\tilde{\sigma}}$ & $\begin{array}{l}\qquad \\
0 \\
0 \\
0\end{array}$ & 5 \\
\hline & ஜ્ন & 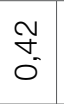 & $\begin{array}{l}\infty \\
0 \\
0\end{array}$ & $\begin{array}{l}\tilde{N} \\
0 \\
0 \\
0\end{array}$ & $\stackrel{n}{\sigma}$ & ○ִ & 吾 \\
\hline & ్ֻసి & $\begin{array}{l}\widetilde{O} \\
0 \\
0\end{array}$ & $\begin{array}{l}\infty \\
0 \\
0\end{array}$ & $\begin{array}{l}\text { P) } \\
\text { ल } \\
0\end{array}$ & \begin{tabular}{l}
0 \\
\hdashline \\
0
\end{tabular} & $\begin{array}{l}\tilde{T} \\
0\end{array}$ & $\widetilde{\Phi}$ \\
\hline & స్ & $\begin{array}{l}\text { 足 } \\
0 \\
0\end{array}$ & $\begin{array}{l}\hat{0} \\
0 \\
0\end{array}$ & $\begin{array}{l}\text { ơ } \\
0 \\
0\end{array}$ & $\frac{10}{\square}$ & $\stackrel{+}{\stackrel{N}{0}}$ & $\stackrel{\Xi}{\tilde{u}}$ \\
\hline & ఫ్స & $\begin{array}{l}\infty \\
0 \\
0 \\
0\end{array}$ & $\begin{array}{l}8 \\
0 \\
0\end{array}$ & $\begin{array}{l}\infty \\
m \\
0 \\
0\end{array}$ & $\frac{\nabla}{\check{0}}$ & $\begin{array}{l}\stackrel{M}{2} \\
0^{-}\end{array}$ & $\frac{8}{8}$ \\
\hline & ஜֶ. & $\begin{array}{l}+ \\
0^{-}\end{array}$ & $\begin{array}{l}\infty \\
0 \\
0\end{array}$ & ơ & $\frac{10}{5}$ & $\begin{array}{l}\infty \\
\stackrel{0}{0} \\
0\end{array}$ & C \\
\hline & ઠิ & $\begin{array}{l}0 \\
N \\
0^{-}\end{array}$ & $\begin{array}{l}\infty \\
0 \\
0\end{array}$ & $\begin{array}{l}\stackrel{+}{m} \\
0_{0}^{\prime}\end{array}$ & $\begin{array}{l}0 \\
\vdots \\
0\end{array}$ & $\begin{array}{l}\infty \\
0 \\
0 \\
0\end{array}$ & U \\
\hline & ్ֶ & $\begin{array}{l}\infty \\
0 \\
0 \\
0\end{array}$ & $\begin{array}{l}\hat{0} \\
0\end{array}$ & $\begin{array}{l}\stackrel{g}{+} \\
0\end{array}$ & $\frac{0}{5}$ & $\begin{array}{l}8 \\
0 \\
0\end{array}$ & $z$ \\
\hline & ఫ్ ఫે & $\begin{array}{l}\infty \\
\infty \\
0^{-}\end{array}$ & $\begin{array}{l}\mathscr{L} \\
0 \\
0\end{array}$ & $\begin{array}{l}M \\
M \\
0 \\
0\end{array}$ & 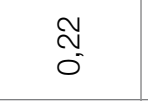 & $\begin{array}{l}\stackrel{M}{R} \\
0\end{array}$ & \\
\hline & ర్ন & $\begin{array}{l}9 \\
R \\
0\end{array}$ & $\begin{array}{l}2 \\
0 \\
0 \\
0\end{array}$ & $\begin{array}{l}\infty \\
m \\
0 \\
0\end{array}$ & 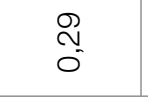 & $\begin{array}{l}8 \\
0 \\
0\end{array}$ & \\
\hline & ఫ્సి & $\begin{array}{l}\overrightarrow{0} \\
0^{\prime}\end{array}$ & $\begin{array}{l}\ell \\
0 \\
0\end{array}$ & $\begin{array}{l}\tilde{m} \\
\tilde{m} \\
0\end{array}$ & $\begin{array}{l}0 \\
\stackrel{N}{ } \\
0\end{array}$ & $\begin{array}{l}\text { ه } \\
0 \\
0\end{array}$ & \\
\hline & 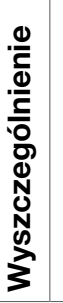 & 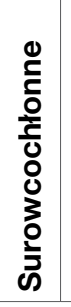 & 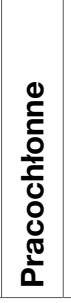 & 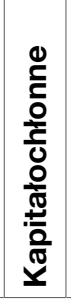 & 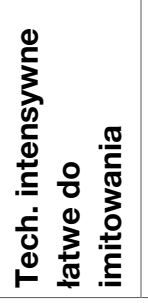 & 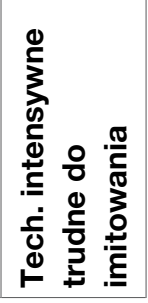 & 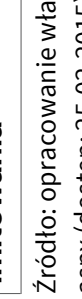 \\
\hline
\end{tabular}


Według uzyskanych wyników w przedziale czasowym 2000-2014 intensywność handlu systematycznie się zmniejszała dla następujących grup towarowych: surowcochłonnych oraz technologicznie intensywnych łatwych do imitowania. Natomiast intensywność handlu wzrosła dla takich grup towarowych jak kapitałochłonne, pracochłonne oraz technologicznie intensywne trudne do imitowania.

\section{Wskaźnik pokrycia importu eksportem}

Wskaźnik pokrycia importu eksportem informuje, w jakim stopniu import danego kraju pokrywany jest przez jego eksport, a przez to pozwala ocenić względną wewnętrzną przewagę lub jej brak nad partnerem handlowym. Obliczono go za pomocą następującego wzoru:

$$
\mathrm{TC}=\frac{E_{i}}{I_{i}} * 100
$$

gdzie:

$\mathrm{E}_{i}$ - eksport z kraju A lub z kraju B do kraju B lub do kraju A

$\mathrm{I}_{i}$ - import kraju do A lub do kraju B z kraju B lub z kraju A

$i$ - grupa towarowa

Biorąc pod uwagę uzyskane wyniki, można zauważyć, że gdy w całym analizowanym okresie lat 2000-2014 wartość amerykańskiego eksportu na rynek chiński pokrywała wartość importu USA z ChRL średnio w ponad $83 \%$, to wartość pokrycia importu eksportem w handlu Chin ze Stanami Zjednoczonymi kształtowała się na zdecydowanie wyższym poziomie i średnio wynosiła 734\%. Taka sytuacja wiąże się z tym, że ChRL w handlu z USA odnotowuje dodatnie saldo bilansu handlowego, podczas gdy dla handlu USA z ChRL, jest ono ujemne. Amerykanie w handlu z Chińczykami odnotowują ponad 100\% pokrycia importu eksportem tylko w przypadku towarów surowcochłonnych. Natomiast, w przypadku handlu ChRL z USA ponad $100 \%$ pokrycia importu eksportem występuje w przypadku pozostałych grup towarowych, czyli towarów pracochłonnych, kapitałochłonnych, technologicznie intensywnych łatwych do imitowania oraz technologicznie intensywnych trudnych do imitowania. Podsumowując, należy zauważyć, że USA specjalizują się w eksporcie na rynek chiński towarów surowcochłonnych, a Chiny w przypadku pozostałych grup towarowych. 
Wymiar handlowy stosunków gospodarczych USA z ChRL w latach 2000-2015

\begin{tabular}{|c|c|c|c|c|c|c|c|}
\hline & & 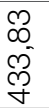 & $\begin{array}{l}0 \\
0 \\
0^{\circ}\end{array}$ & 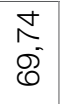 & $\begin{array}{l}\infty \\
\infty \\
\wedge\end{array}$ & $\begin{array}{l}\stackrel{\infty}{N} \\
\stackrel{N}{\infty}\end{array}$ & \\
\hline & & 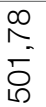 & $\begin{array}{l}\text { Oे } \\
6\end{array}$ & $\begin{array}{l}8 \\
\hat{0} \\
\hat{0}\end{array}$ & $\begin{array}{l}\underset{\sim}{\sim} \\
\infty\end{array}$ & 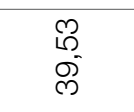 & $\bar{\psi}$ \\
\hline & š & 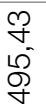 & $\begin{array}{l}\stackrel{5}{0} \\
0\end{array}$ & $\begin{array}{l}M \\
M \\
D \\
0 \\
0\end{array}$ & $\begin{array}{l}\hat{N} \\
\infty 0^{\prime}\end{array}$ & $\begin{array}{l}0 \\
\text { o } \\
\infty \\
\infty\end{array}$ & \\
\hline & 5 & $\begin{array}{l}\tilde{N} \\
m \\
0 \\
0 \\
0\end{array}$ & $\begin{array}{l}\text { ô } \\
\delta^{\circ}\end{array}$ & $\begin{array}{l}9 \\
N \\
0 \\
0\end{array}$ & $\begin{array}{l}8 \\
0\end{array}$ & $\begin{array}{l}\frac{M}{-} \\
\frac{\sigma}{\sigma}\end{array}$ & 6 \\
\hline & s. & \begin{tabular}{l}
$\frac{10}{5}$ \\
\multirow{N}{*}{}
\end{tabular} & $\begin{array}{l}9 \\
\mathcal{Y} \\
6\end{array}$ & $\begin{array}{l}8 \\
0 \\
i 5\end{array}$ & $\begin{array}{l}\bar{N} \\
\sigma\end{array}$ & 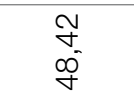 & \\
\hline & S. & $\begin{array}{l}\bar{\sigma} \\
\text { s. } \\
\text { s. }\end{array}$ & $\begin{array}{l}\infty \\
\stackrel{\infty}{\infty} \\
\infty^{-}\end{array}$ & $\begin{array}{l}\bar{t} \\
\tilde{\rho} \\
\tilde{c}\end{array}$ & $\frac{10}{\sigma^{\circ}}$ & 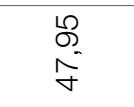 & \\
\hline & : & $\begin{array}{l}\stackrel{3}{+} \\
\stackrel{N}{N}\end{array}$ & $\begin{array}{l}\stackrel{\infty}{\sim} \\
\stackrel{f}{f}\end{array}$ & $\begin{array}{l}\stackrel{d}{N} \\
\dot{\sim}\end{array}$ & $\begin{array}{l}\text { o } \\
0 \\
\infty \\
\infty\end{array}$ & $\begin{array}{l}\bar{m} \\
\omega \\
0 \\
D\end{array}$ & \\
\hline & S. & $\begin{array}{l}\bar{\alpha} \\
\infty \\
\infty \\
N^{-}\end{array}$ & $\begin{array}{l}N \\
\infty \\
\infty\end{array}$ & $\begin{array}{l}\vec{J} \\
\stackrel{d}{d}\end{array}$ & $\begin{array}{l}\stackrel{\infty}{N} \\
\infty \\
\infty\end{array}$ & $\begin{array}{l}\widetilde{N} \\
\text { D) } \\
\infty\end{array}$ & 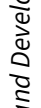 \\
\hline & : & 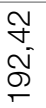 & \begin{tabular}{l}
$\widetilde{O}$ \\
\multirow{\sigma}{*}{}
\end{tabular} & $\begin{array}{l}\mathbb{Z} \\
\tilde{N}^{-}\end{array}$ & $\begin{array}{l}\stackrel{Q}{\wedge} \\
\stackrel{1}{\wedge}\end{array}$ & $\begin{array}{l}\infty \\
\infty \\
10 \\
10\end{array}$ & 8 \\
\hline & مै & $\begin{array}{l}\text { D. } \\
\text { D } \\
\text { D } \\
\end{array}$ & $\begin{array}{l}\tilde{O} \\
\tilde{f}\end{array}$ & $\begin{array}{l}\tilde{O} \\
\stackrel{0}{N}\end{array}$ & $\bar{\sigma}^{-}$ & $\begin{array}{l}0 \\
0 \\
\text { Ni }\end{array}$ & \\
\hline & 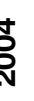 & 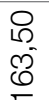 & $\begin{array}{l}\infty \\
\stackrel{\infty}{\infty} \\
\mathcal{n}^{-}\end{array}$ & \begin{tabular}{l}
0 \\
0 \\
0 \\
0 \\
\multirow{N}{*}{}
\end{tabular} & $\begin{array}{l}\text { 8) } \\
\infty\end{array}$ & $\begin{array}{l}D_{0} \\
\frac{-}{5}\end{array}$ & \\
\hline & : & 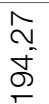 & $\begin{array}{l}0 \\
M \\
m \\
m\end{array}$ & $\begin{array}{l}\tilde{\omega} \\
\widetilde{\infty} \\
\tilde{N}\end{array}$ & $\begin{array}{l}\text { Y } \\
\text { o }\end{array}$ & $\begin{array}{l}\text { of } \\
\text { N }\end{array}$ & \\
\hline & לू. & 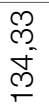 & $\begin{array}{l}R \\
\sim \\
\sim\end{array}$ & $\begin{array}{l}\dot{J} \\
\sigma \\
\sigma\end{array}$ & $\begin{array}{l}\frac{0}{\sim} \\
\stackrel{\sim}{\sim}\end{array}$ & $\begin{array}{l}\text { q } \\
\text { in }\end{array}$ & \\
\hline & ర్ & 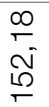 & in & $\begin{array}{l}\bar{\infty} \\
\infty \\
\infty\end{array}$ & $\begin{array}{l}\stackrel{\curvearrowright}{N} \\
\stackrel{N}{\sim}\end{array}$ & 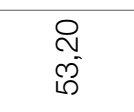 & \\
\hline & ถి & $\underset{c}{\bar{c}}$ & $\begin{array}{l}\hat{N} \\
\text { i }\end{array}$ & $\begin{array}{l}\stackrel{\rho}{\rho} \\
\infty^{-} \\
\leftarrow\end{array}$ & $\begin{array}{l}0 \\
\varnothing \\
+\end{array}$ & $\begin{array}{l}\bar{\delta} \\
\stackrel{y}{y}\end{array}$ & \\
\hline & 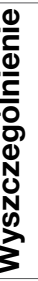 & 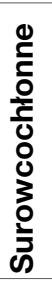 & 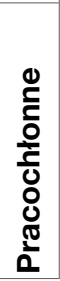 & 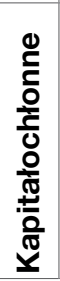 & 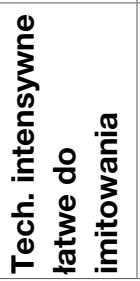 & 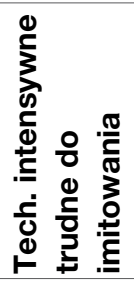 & \\
\hline
\end{tabular}




\section{Kształtowanie się stopnia dopasowania struktury podaży eksportowej Stanów Zjednoczonych do struktury popytu importowego Chin oraz struktury podaży eksportowej Chin do struktury popytu importowego USA}

Dotychczasowe kształtowanie się rozmiarów i struktury amerykańskiego importu $\mathrm{z}$ Chin można $\mathrm{w}$ świetle odpowiedniego dorobku teoretycznego uważać za uzasadnione w tym głównie sensie, że USA dysponuje ewidentną przewagą nad ChRL pod względem bogactwa surowców naturalnych (głównie zasobów ropy naftowej i gazu ziemnego).

Wskaźniki stopnia dopasowania struktury podaży eksportowej USA do struktury popytu importowego Chin w latach 2000-2014 obliczono według wzoru:

$$
\mathrm{C}_{i j k}=1-\frac{\sum\left|y_{i}-x_{j}\right|}{2}
$$

gdzie:

$\mathrm{m}_{i k}$ - udział importu grupy towarowej „i” w imporcie globalnym Chin lub udział importu grupy towarowej „i” w imporcie globalnym USA $\mathrm{x}_{i j}$ - udział grupy towarowej ,j” w eksporcie USA do Chin lub udział eksportu grupy towarowej ,j” w eksporcie Chin do USA.

Wskaźnik $\mathrm{C}_{i j k}$ waha się w granicach $0-1$, przy czym wartość 0 oznacza, że towary (grupy towarowe) $i$ eksportowane przez kraj $j$ nie są w ogóle przedmiotem importu do wybranego kraju. Odpowiedni wskaźnik osiąga natomiast maksymalną wartość 1, gdy udziały importu towaru (grup towarowych) $i, . ., n$ analizowanego partnera, w naszym przypadku Chin, są idealnie takie same, jak odpowiednie udziały w eksporcie analizowanego kraju, w naszym przypadku USA. Oczywiście im wyższa wartość wskaźnika $C_{i j k}$, tym lepiej struktura podaży eksportowej analizowanego kraju jest dopasowana do struktury popytu importowego Chin lub odpowiednio USA 9 .

W całym analizowanym okresie obserwowano proces wzrostu stopnia dopasowania struktury podaży eksportowej USA do struktury popytu importowego ChRL. W latach 2000-2008 wskaźnik ten wzrósł z poziomu 0,74 do poziomu 0,93 . W 2009 odnotowany był spadek do poziomu roku 2000, ale w latach następnych znowu miał miejsce jego wzrost. W 2014 roku równał się on 0,75 . Świadczy to nie tylko o lepszym dopasowaniu podaży eksportowej USA do struktury popytu importowego ChRL, ale i o tym, że towary amerykańskie na rynku chińskim cechował wyższy stopień konkurencyjności.

$9 \quad$ Ibidem, s. 151. 


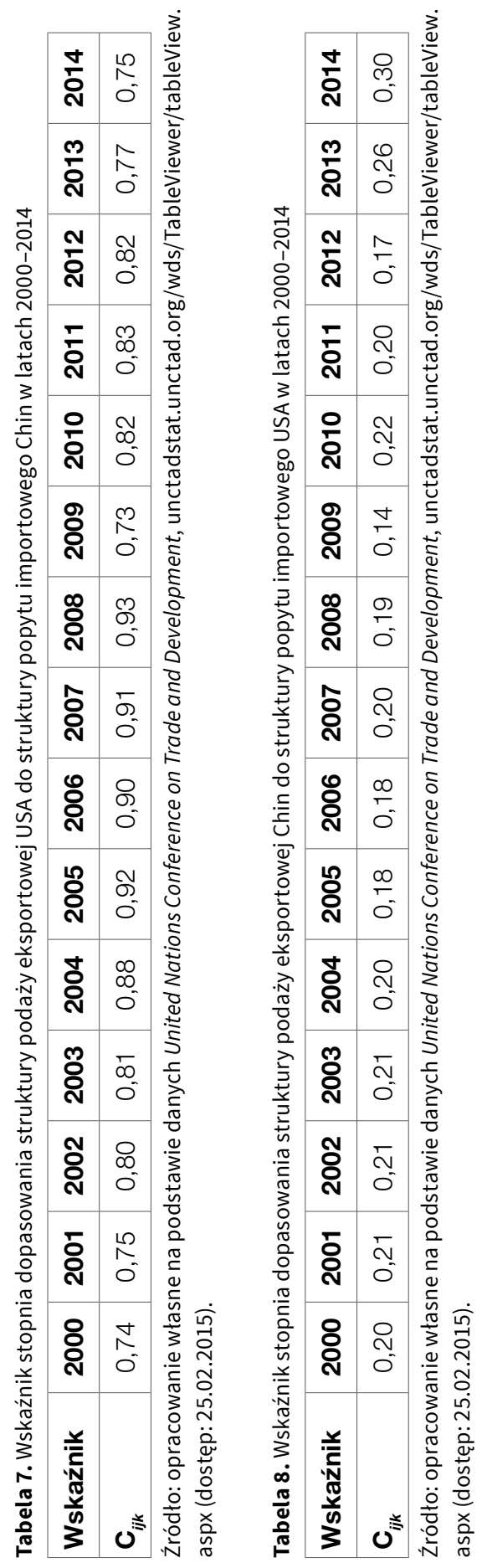




\section{Podsumowanie}

Podsumowując, należy zauważyć, że w latach 2000-2015 miał miejsce wzrost amerykańsko-chińskich obrotów handlowych. I tak, w tym czasie eksport amerykański do Chin wzrósł ponad 7-krotnie, a eksport chiński do USA - ponad 4,5-krotnie. W latach 2000-2014 udział amerykańskiego eksportu do ChRL w eksporcie USA ogółem był prawie sześciokrotnie mniejszy od udziału chińskiego eksportu do USA w eksporcie ChRL ogółem. Natomiast udział amerykańskiego importu z ChRL w imporcie USA ogółem był ponad dwukrotnie większy od udziału chińskiego importu z USA w imporcie ChRL ogółem. W tym samym czasie średni udział eksportu USA do Chin w globalnym eksporcie amerykańskim wynosił 3,36\%, podczas gdy udział chińskiego eksportu do USA w globalnym eksporcie Chin prawie $30 \%$.

Takie występowanie znacznej asymetrii w wymianie handlowej między Stanami Zjednoczonymi a Państwem Środka wiąże się ze zróżnicowanym poziomem PKB omawianych państw. Na przestrzeni lat 2000-2014 udział amerykańsko-chińskich obrotów handlowych w PKB USA średnio wynosił 2,47\%, a w PKB Chin - 9,46\%. Dane te wskazują przede wszystkim na istnienie różnic $\mathrm{w}$ rozwoju gospodarczym obu państw, które wynikają z wielkości wyprodukowanego przez USA i ChRL PKB oraz ze stopnia uzależnienia ich gospodarek od handlu zagranicznego.

Analizując w latach 2000-2014 strukturę towarową eksportu USA do Chin należy zauważyć, że struktura towarowa amerykańskiego eksportu na rynek chiński była stabilna a wszystkie grupy towarowe cechował trend wzrostowy, aczkolwiek nie był on tak znaczący, jak w przypadku amerykańskiego eksportu na rynek chiński. Średnio wzrost ten wyniósł tylko 4,4 razy, wtedy gdy w przypadku amerykańskiego eksportu na rynek chiński - 17,6 razy.

Struktura rodzajowa wymiany handlowej między USA i ChRL cechowała się tym, że w badanym przedziale czasowym po stronie amerykańskiego eksportu na rynek chiński dominowały towary technologiczne intensywne trudne do imitowania (21,6 mld dolarów); surowcochłonne (19,8 mld dolarów) oraz technologiczne intensywne łatwe do imitowania (8,6 mld dolarów). Natomiast w przypadku chińskiego eksportu na rynek amerykański do grupy tej należały wyroby pracochłonne (126,3 mld dolarów); technologiczne intensywne łatwe do imitowania ( 97,7 mld dolarów), technologiczne intensywne trudne do imitowania (46,1 mld dolarów) oraz wyroby kapitałochłonne (13,4 mld dolarów).

Analizując wielkość wymiany handlowej między USA i ChRL należy zauważyć, że handel amerykańsko-chiński jest wymianą typu międzygałęziowego. 
Uzyskane wyniki wskazują, że w badanym okresie USA osiągały przewagę komparatywną w przypadku następujących sekcji: towarów surowcochłonnych, technologicznie intensywnych trudnych do imitowania oraz $\mathrm{w}$ niewielkim stopniu w przypadku towarów kapitałochłonnych. Z kolei Chiny w handlu z USA osiągały przewagę komparatywną w przypadku towarów pracochłonnych oraz w przypadku towarów technologicznych intensywnych łatwych do imitowania.

Natomiast zauważono, że omówionemu wcześniej wzrostowi stopnia i znaczenia wymiany (komplementarności) międzygałęziowej między Stanami Zjednoczonymi i ich azjatyckim partnerem towarzyszy spadek intensywności i znaczenia wymiany (komplementarności) typu międzygałęziowego.

W przypadku pokrycia importu eksportem należy zauważyć, że znacznie lepiej wypada ChRL, ponieważ w wymianie handlowej z USA osiąga ona dodatnie saldo bilansu handlowego. Biorąc pod uwagę uzyskane wyniki, można zauważyć, że gdy w całym analizowanym okresie lat 2000-2014 wartość amerykańskiego eksportu na rynek chiński pokrywała wartość importu USA z ChRL średnio w ponad 83\%, to wartość pokrycia importu eksportem w handlu Chin z ich amerykańskim partnerem kształtowała się na zdecydowanie wyższym poziomie i średnio wynosiła $734 \%$.

Taki stan rzeczy ma wpływ na stadium kształtowania się stopnia dopasowania struktury podaży eksportowej USA do struktury popytu importowanego Chin. W całym analizowanym okresie obserwowano proces wzrostu stopnia dopasowania struktury podaży eksportowej USA do struktury popytu importowego ChRL. W latach 2000-2008 wskaźnik ten wzrósł z poziomu 0,74 do poziomu 0,93. W 2009 roku odnotowany był spadek do poziomu roku 2000, ale w latach następnych znowu miał miejsce jego wzrost. W 2014 roku równał się on 0,75 . Świadczy to nie tylko o lepszym dopasowaniu podaży eksportowej USA do struktury popytu importowego Chin, ale i o tym, że towary amerykańskie na rynku chińskim cechował wyższy stopień konkurencyjności.

\section{Bibliografia}

15 lat temu wywiad USA opublikowat prognozy na 2015 r. W wielu przypadkach się nie pomylit, „Polityka”, http://www.polityka.pl/tygodnikpolityka/swiat/1623809,1,15-lat-temu-wywiad-usa-opublikowal-prognozy -na-2015-r-w-wielu-przypadkach-sie-nie-pomylil.read.

CABESTAN J.-P., Polityka zagraniczna Chin, Warszawa 2013. 
INTERNATIONAL Trade Center, http://www.trademap.org/Bilateral_TS.aspx. MISALA J., Międzynarodowa konkurencyjność gospodarki narodowej, Warszawa 2011.

NOWA polityka USA wobec Chin - cła wyrównawcze na import powlekanego papieru, http://gca.org.pl/pl_PL/usa-congress-eyes-china-trade-action/.

OBAMA w Chinach: zabieranie dziecku cukierka, http://3obieg.pl/obama-wchinach-zabieranie-dziecku-cukierka.

PACUŁA P., Duopol 2020? Stan relacji amerykańsko-chińskich i perspektywy ich rozwoju, „Bezpieczeństwo narodowe” 2011, nr 20, tom IV.

UNITED Nations Conference on Trade and Development, unctadstat.unctad. org/wds/TableViewer/tableView.aspx.

THE World Bank, http://databank.worldbank.org/data/reports.aspx?sour$\mathrm{ce}=$ world-development-indicators. 